All this gives grounds to consider grammatical particles as subjective-modal forms and to consider them as an important means of expressing subjective modality in an artistic text. On the one hand, we see the prospects of such research in the fact that they intensify scientific interest in other parts of language, other means of expressing modality in it, and on the other - in the creative heritage of modern Ukrainian writers, including Volodymyr Shovkoshytnyy.

Keywords: grammatical particle, modality, shade of meaning, statement, literary text, V. Shovkoshytnyy.

Vitae

Tetiana Vilchynska is Doctor of Philology, Professor, Dean of Faculty of Philology and Journalism, Professor of Department of General Linguistics and Slavic Languages in Volodymyr Hnatiuk Ternopil National Pedagogical University. Her research interests include cognitive linguistics, linguoculturology, and text linguistics.

Correspondence: tetyana_v@ukr.net

Надійшла до редакції 4 березня 2021 року

Рекомендована до друку 18 березня 2021 року

Мария Конюшкевич

DOI 10.31558/1815-3070.2021.41.9

УДК 81.367 .634

\title{
ИСЧИСЛИМОСТЬ ПОКАЗАТЕЛЕЙ СИНТАКСИЧЕСКОЙ СВЯЗИ КАК ФАКТОР ИХ КАТЕГОРИАЛЬНОСТИ В СИСТЕМЕ ЯЗЫКА
}

На основе дефиниционного анализа доказывается, что называемые в дефинициях признаки союза как части речи не являются критерием отличия его от изофункциональных ему единии. Для инвентаризачии союзных средств предлагается использование фактора их исчислимости, для чего на примере скрепь то, что проводится моделирование союзных соединений предложно-падежных словоформ тог с союзом что. В итоге получено 28 скреп типа без того, что; к тому, что; под тем, что; и т. д. Приводятся примеры употребления всех полученных скреп с необходимыми комментариями. Доказано, что категориальность союзных средств определяется фактором их исчислимости, а союзная функиия употреблением в коммуникации.

Ключевье слова: валентность, парадигма, дифференщирующий признак, скрепа, словоформа, союз.

«...как мало пока накоплено «положительных» знаний о скрепах, как беден и неупорядочен метаязык... Еще предстоит не только выявлять структурные типы скреп, но и продолжать работу над инвентаризацией скреп, составлением относительно полного списка «элементов множества», подлежащего упорядочению под разными углами зрения»

(Черемисина, Колосова1987: 108).

Постановка проблемы начинается уже с эпитета - цитаты из монографии, жанр которой авторы скромно обозначили как очерки, но по глубине обозначенных проблем её можно считать программной для широкого исследования средств синтаксической связи, массив которых выходит далеко за пределы традиционно выделяемого перечня «классических» союзов. Одна из сформулированных авторами задач - определение границ класса показателей синтак- 
сической связи и необходимая для этого простая инвентаризация союзных средств для дальнейших грамматических описаний и лексикографической манифестации.

Анализ литературы. Количество союзов в русском языке по данным словарей и грамматик колеблется с разбежкой в несколько сотен единиц: в дифференцированных словарях подаются списки из 208 союзов («Словарь структурных слов» 1997; «Объяснительный словарь» 2003); в монографии о союзах - 569 (Завьялов 2008: 216-232), по данным в (Черемисина, Колосова 1987: 136) их - 668, в т. ч. 576 союзов и аналогов союзов и 92 союзных слова. Столь разительные расхождения в статистике объективны и объяснимы: «в отсутствие более подробных изысканий, отнесение слова к союзам или к тому или иному классу союзов следует признать до некоторой степени условным. Сколько-нибудь точная статистика многих союзов, особенно частотных, многозначных, двойных зачастую оказывается и вовсе невозможной», особенно если учесть, что «иногда в функции союзов употребляются знаменательные части речи (правда), что существенно затрудняет их статистику»; обе цитаты из (Апресян, Пекелис 2012).

Судя по приведенному примеру релятива правда как союза, можно утвердиться в правоте мнения М. В. Ляпон о том, что «необходим пересмотр вопроса о содержании категории “союз", т. е. принципиальный выход (не только в исследованиях по тексту, но и в нормативно-описательных грамматиках) за пределы “чистого союза" - за рамки соединителей, принятых грамматистами в класс союзов в качестве идеальных представителей этого класса: вопрос о реальном фонде соединителей, который должен фиксировать словарь и грамматика, может быть решен силой авторитета самого́ естественного языка» [Ляпон 1986, с. 195-196].

Думается, что в свете теории о полевой структуре Языка ставить задачу исчисления показателей синтаксической связи по крайней мере утопично, ибо если ядро данного класса обозримо, то границы периферии союзных средств размыты и прозрачны для включения в этот класс представителей иных классов. Задача осложняется еще и тем, что само понимание союза трактуется как в узком (Прияткина 1978), так и в широком (Черемисина, Т. А. Колосова 1987) смысле. Мы ограничиваемся здесь указанием только на два по полярности мнений источника, поскольку необходимый для наших задач обзор трактовок союза дан в (Завьялов 2008), а литература по природе служебных слов в целом и союзов в частности обширна и необозрима. Появились и новации в лексикографической манифестации служебных слов, в том числе и союзов. Это, во-первых, всестороннее портретирование служебного слова по объяснительному принципу в коллективных трудах ученых Дальневосточного государственного университета во главе с А. Ф. Прияткиной («Словарь служебных слов» 2001; «Служебные слова» 2017) в целях создания Машинного фонда служебной лексики; во-вторых, разработка методологических основ функционально-лексикографической грамматики служебности и представление структуры словарной статьи в такой грамматике в (Загнітко 2012).

Цель и задачи исследования. Методология и методика. Мы солидарны с широкой трактовкой союза, причем не столько как части речи, сколько как синтаксического союзного средства, обнаруживающего свои функции в высказывании и тексте. При этом мы не ставим перед собой цель установить лингвистический статус показателя связи в той или иной конструкции, которую этот показатель образует. Нам важна на первое время сама инвентаризация таких средств, ибо даже если союзную функцию выполняет не собственно союз, а сочетание его с другими словами-несоюзами или иная часть речи, выступившая в союзной функции, или даже фразеосхема, фиксация таких единиц необходима и в словаре, и в грамматических описаниях.

При таком широком подходе возникает вопрос, по каким критериям можно и следует определить границы самой категории показателя связи, особенно если это аналитическая структура. Полагаем, что к решению указанной проблемы можно подойти с позиций полевой структуры категории союза, а именно: теоретически функциональное (точнее - морфосинтаксическое) поле союза представляется как комплекс дифференцирующих признаков (ДП), которые в ярком их выражении и полном комплекте образуют ядро поля, а зоны, образуемые 
конституентами со слабо выраженными признаками или с их неполной комплектностью, занимают периферийные зоны поля.

Для выявления ДП поля союза проведем сравнительный дефиниционный анализ (выявленные признаки выделены).

1) Дефиниция авторов раздела «Союз» «Русской корпусной грамматики» (с частичной элиминацией ссылок в примерах): «Союз - служебная часть речи, которая используется для выражения синтаксической (сочинительной или подчинительной) связи единиц разной природы и объема, от клауз (Исследования продолжаются, и гипотезы множатся) до словосочетаний (Яблоки и чернослив традиционно подают с гусем) и даже компонентов слов (двух- и трехэтажные дома)» (Апресян, Пекелис 2012).

2) «...для союзов обязательными характеристиками являются конструктивные свойства, организация синтаксических построений» («Словарь служебных слов» 2001: 6). «Союзы, как класс служебных слов, специально предназначены для выражения отношений между частями (составными элементами) синтаксической единицы. Тем самым союз осуществляет грамматическую связь языковых элементов и создает некоторое целое. Это и определяет главное содержание словарной статьи для каждого союза» («Словарь служебных слов» 2001: 99).

3) Основными признаками союза являются: «1) способность образовывать синтаксическую конструкцию (конструирующая функция), 2) формально-синтаксическая позиция, в которой закрепляется чистая функция связи» (Прияткина 1978: 55).

4) «Союз - служебная часть речи, оформляющая связь между словоформами в составе простого предложения, между частями сложного предложения, а также внутритекстовые связи в рамках сложного синтаксического целого» («Русский язык» 1997: 526).

5) Союз - «класс служебных слов, оформляющих синтаксические связи предложений и синтаксические связи слов. Связующая функция является для союза основной. ...Союз обозначает содержательные отношения между связываемыми единицами... Союз автономен в составе предложения» («Лингвистический энциклопедический словарь» 1990: 484).

Итак, союз имеет следующие ДП:

1) ДП-1 - союз является служебным словом; таким же признаком обладают предлоги, связки и другие разновидности строевой лексики (модальные глаголы, глаголыэкспликаторы, существительные-классификаторы; см. (Всеволодова 2000). Однако роль скреп выполняет множество и неоднословных показателей связи.

2) ДП-2 - союз связывает; по этой функции для всех показателей связи подходят термины «скрепа», «коннектор», «союзное средство», «функтив».

3) ДП-3 - союз связывает единицы строения разной природы, - предикативные единицы (клаузы), словосочетания в широком смысле (синтагмы), фразы (высказываний) в тексте, и даже компоненты слова (в композитах); для всех связываемых компонентов удобен общий термин «конъюнкт»; если речь идет о частях сложных предложений, остаются традиционные термины - «предикативная единица», «главная часть», «придаточная часть».

4) ДП-4 - союз конструирует, т. е. образует единицу построения (синтаксическую конструкцию) - ряд однородных членов, сложное предложение, сверхфразовое единство, текст.

5) ДП-5 - в единице построения союз выражает отношения между единицами строения; иначе говоря, союз - формант отношений между компонентами образованной им единицы построения.

6) ДП-6 - у союза формально-синтаксическая фиксированная позиция. Данный ДП охватывает далеко не все показатели связи - частицы в роли союза, союзные слова, двухчастные союзы и др. 
7) ДП-7 - союз автономен в составе единицы построения. Это означает, что из категории союза исключаются союзные слова, которые наряду с союзной выполняют и функцию членов предложения.

Результаты дефиниционного анализа. Таким образом, полученный комплекс из семи ДП позволяет а) очертить ядро поля, в которое войдут только однословные союзы, которых в (Словарь структурных слов 1997) мы нашли всего лишь 49 единиц, а однозначных, без омонимии, и вовсе только 9 (если, зато, ибо, итак, либо, поскольку, притом, причем, чем).

Если же учесть комментарии и описание дополнительных признаков, которые опровергают самое дефиницию, то за пределами ядра поля оказывается большинство союзов. Например: а) союзы бывают неоднословные, или составные, и «отнесение таких словосочетаний к классу союзов, во многих случаях оказывается условным» («Лингвистический энциклопедический словарь» 1990: 484) (минус ДП-1); б) союзы бывают двухчастные (минус ДП-6), одноместные, двухместные, многоместные (минус ДП-6; ДП-7); в) «место подчинительного союза не является строго фиксированным» («Лингвистический энциклопедический словарь» 1990: 484) (минус ДП-6); «на периферии класса союзов находятся 1) аналоги союзов (группа слов с квалифицирующим лексическим значением; 2) союзно-наречные сочетания» [«Лингвистический энциклопедический словарь: 484-485») (минус ДП-1, ДП-7). В поле союза допускаются даже аналитические структуры, если они связывают конъюнкты разной природы, организуют целое и выражают в этом целом отношения между конъюнктами (ДП- 2, 3, 4, 5).

Таким образом, конституенты категориального поля союза не только служебные слова как части речи, но и сочетания слов, и знаменательные слова, обладающие лексическим значением и синтаксической позицией члена предложения. Где же поставить внешнюю границу класса союзов? Думается, такая граница стоит на четырех «китах» - ДП-2, ДП-3, ДП-4; ДП-5: союз - морфосинтаксическая единица, которая связывает особые единицы строения, образует особую единицу построения и выражает отношения между ними. А какие еще у этой единицы лексические и синтаксические свойства и функции, из скольких элементов она состоит, какие позиции она может занять в построенной ею конструкции - это второстепенные признаки, не мешающие ей выполнять функцию союзного средства.

На наш взгляд, необходимо иметь в виду еще одно свойство союзного средства в его и узком, и широком понимании. Морфологический подход мешает осознавать синтаксическую природу союза. Ведь в единице построения показатель синтаксической связи представляет собой непредикативную пропозицию, содержанием которой являются отношения между конъюнктами, а выражением - звуко-графическая оболочка скрепы, которая сама по себе уже способна выразить отношение, без лексического наполнения конъюнктов. Даже так называемый асемантический союз $u$ пропозитивен: синтагма $A u B$ означает, что между $A$ и $B$ отношения аналогичности, покоящейся на некоем третьем, которое содержится в $A$ и $Б$ и поэтому способно их объединить именно этим союзом. Именно поэтому можно соединять этим союзом и понятийно тождественные $A$ и 5 (милые и дорогие), и понятийно полярные $A$ и $Б$ (лед и пламень). Именно в силу своей синтаксичности и пропозициональности данный союз может связать и не соответствующие между собой в понятийно-словарном отношении слова (например, чернильница и подушка) в высказывании $B$ этом катаклизме уцелели только чернильница и подушка). Не случайно в коммуникации встречаются «голые» пропозиции, понимаемые и заполняемые собеседниками соответственно теме коммуникации: Как только, так сразу; Еще не, а уже; Если..., то; Стоило..., как; - Вы замужем или?.. - Или.

Скрепа так же, как и предлог, предикатна и, как любой предикат, имеет валентность и окружена актантами. В приведенном выше высказывании актанты - чернильница и подушка, в сложных конструкциях актанты - соединяемые скрепой предикативные части. Скрепа обладает левой и правой валентностями, сила которых зависит не только от свойств самой скрепы, но и от элементов в актантах. Так, левую валентность скрепы в сложноподчиненном предложении обеспечивают в главной части управляющие глаголы, компаративы, опорные слова, указательные местоимения. Некоторые из них настолько прочно сцеплены союзом, что обра- 
зуют с ней новую, более сложную скрепу. Правую валентность скрепы реализует лексическое наполнение придаточной части и / или отдельные ее слова.

Таким образом, чтобы скрепа сконструировала синтаксическую конструкцию, готовую к коммуникации (высказывание), элементы частей должны соответствовать скрепе, а она им. И это соответствие в категориальном отношении гораздо крепче и регулярнее, чем нам кажется. Так, М. И. Черемисина скрепу тог, что считает целостным показателем связи (Черемисина 1982) и одинаковым как в изъяснительных сложных предложениях, так и в конструкциях типа Утро началось $\boldsymbol{c}$ того, что пригорела каша (знаменитый пример В. А. Белошапковой), объясняя это тем, что «если предикативная часть со скрепой препозитивна, то в препозицию вместе с союзом уходит и местоименный компонент скрепы. В нормативной речи цепочка то2, что не разрывается» (Черемисина, Колосова 1987: 147). И далее: «Показателем связи в подобных конструкциях мы считаем всю цепочку то, что (то, чтобы; то, как), оценивая ее как одноместный показатель связи» (Черемисина, Колосова 1987: 147-148).

«За кадром» остается вопрос, речь идет об одной скрепе со всеми падежными словоформами ее местоименного компонента или каждая падежная словоформа то $_{2}$ порождает и новую скрепу - того, что; тому, что и т. д. Эти словоформы М. И. Черемисина расценивает как «падежные окончания» придаточной части: «Падежные показатели, «адресованные» предикативной единице, которых не способно принять русское глагольное сказуемое, принимает местоименный компонент скрепы - то. Сравним нормативное предложение Я рад тому, что ты приехал и шутливо-просторечное С приехалом! (Н. Дубов), т. е. ...флексию датива принимает именно глагол» (Черемисина, Колосова 1987: 148).

А как быть со скрепами, в которых падежные словоформы тог употреблены с предлогами, которых, как выявлено, в языке огромное множество: несмотря на то, что; в расчете на то, что; при том, что; с тем, что; к тому, что и т. д.? М. И. Черемисина об этом не пишет, но признает, что «управление, исходящее от главного сказуемого и направленное на зависимую ПЕ, и по-русски выражается с помощью падежей и их уточнителей - предлогов, только крепятся они не непосредственно к сказуемому зависимой части, стоящему в ее финале, а к инициальному местоименному компоненту скрепы» (Черемисина, Колосова 1987: 148).

Обращается ее внимание и на другие сцепления - скрепу, где оба компонента прономинальны (то, что́), а также «может быть, следовало бы выделить как особую и скрепу то, $\kappa=$, например: То, куда, откуда, к кому и зачем он пришел, осталось тайной. Здесь компонент mо соотносится с $K$-местоимением или $K$-местоименным наречием. Но свойства этого “семейства скреп" и отношений элементов внутри его еще ожидают исследования. Сейчас достаточно сказать, что скрепу то 2 что составным союзом мы не считаем, она имеет особую, иную природу» (Черемисина, Колосова 1987: 148).

Повторимся, мы не ставим своей целью давать лингвистическую квалификацию сцеплениям $T$-слов и $K$-слов в сложноподчиненном предложении. Но если учесть предикатные и валентностные свойства подобных сцеплений как формантов отношений между частями, такую же валентностную силу указательных местоимений, управляющих глаголом-сказуемым придаточной части, а также самостоятельность каждого падежного значения, то следует признать в каждой из $T$-словоформ и в каждой из $K$-словоформ самостоятельную единицу, а варианты компоновок из таких словоформ считать отдельными служебными скрепами. И каким бы большим ни было количество таких сцеплений, их список конечен и исчислим, а следовательно, поддается инвентаризации.

Докажем это на одном эксперименте. Но предварительно отметим, что диапазон синтаксических функций слова то настолько широк, а семантические и грамматические признаки этого слова в каждой из функций настолько различны, что есть основания говорить о явлении омонимии между функциональными разновидностями данной лексемы. Анализ $T$-слов - грамматических омонимов тоm / mо был представлен в ряде наших публикаций, например, в (Конюшкевич 2010), здесь же приведем лишь парадигмы $T$-слов. 
В грамматическом отношении указанные $T$-слова представлены семью падежными парадигмами словоформ:

1) тот: муж., жен., ср. рода ед. и мн.ч. (тот сын; та дочь; то существо; те сыновья / дочери / существа) - адъективная парадигма из 24 словоформ;

2) тот: одушевл. личн. сущ. муж. рода, ед. ч. (mom, кто...) - субстантивная парадигма из 6 словоформ;

3) та: одушевл. личн. сущ. жен. рода, ед. ч. (жен. та, которая...) - субстантивная парадигма из 6 словоформ;

4) то: одушевл. неличн. сущ. ср. рода, ед.ч. (то, которое) - субстантивная парадигма из 6 словоформ -;

5) те: одушевл. личн. сущ. муж, жен., мн. ч. (те, кто) - субстантивная парадигма из 6 словоформ;

6) тол: неодуш. сущ. ср. p. (то, что́) - субстантивная парадигма из 6 словоформ;

7) тог: пустое сущ. ср. р. то, что) - субстантивная парадигма из 6 словоформ.

Всего 60 словоформ Т-слов.

В сочетании с предлогами эти 60 словоформ теоретически должны образовать столько предложно-падежных словоформ $c$ то, сколько произведено от умножения 60 словоформ на количество употребляемых с ними предлогов. В русском языке 21 однословный немотивированный первообразный предлог без вариантов (в РГ-80 их 36 с вариантами). Их перечень - с вариантами: без/безо, в/во, для, до, за, из/изо, к/ко, кроме, меж /между, на, над/надо, о / об, от / ото, перед / передо, пред / предо, по, под / подо, при, ради, с/со, у, через /чрез/черезо ; подсчет М. В. Всеволодовой на основании «Русской грамматики-80 (Всеволодова 2014: 85); перечень предлогов без вариантов: без, в, для, до, за, из, к, кроме, между, на, над, о, от, перед, $n o, n o d, n p u, p a d u, c, y$, через - всего 21 предлог. Учтем, что 7 предлогов из этого списка (в, за, $н a, o, n o, n o d, c)$ управляют двумя падежами, т. е. фактически представлены двумя предлогами, следовательно, всех предлогов 28. Умножаем 60 на 28 и получаем 1680 предложно-падежных словоформ. И это абсолютное количество, не больше! Все ли они способны быть реализованы в языке?

М. В. Всеволодова показала, что «не для каждого класса слов существительных реальны все предложно-падежные формы», например, едва ли возможны формы под мартом, на мае, при вторнике и под. (Всеволодова и др. 2014: 20). Скорее всего данное ограничение на полноту парадигмы словоформ может иметь место и в $T$-сочетаниях: *nод тем мартом, *на том мае, *nри том вторнике и под., но поскольку мы не располагаем таким ограничительным списком и в наши задачи пока не входит его составлять, будем исходить из того, что такие ограничения с $T$-словами отсутствуют. Тогда с представленным списком первообразных предлогов мы получаем следующий перечень предложно-падежных $T$-словоформ:

БЕЗ: без того (сына), без той (дочери), без того (существа), без тех (сыновей, дочерей, существ); без того, без той, без того, без тех (муж, жен., ср.); без того ; без того - - всего 10 словоформ;

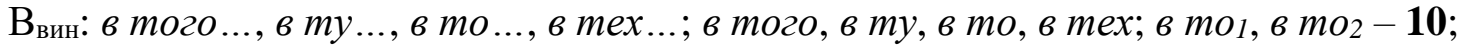

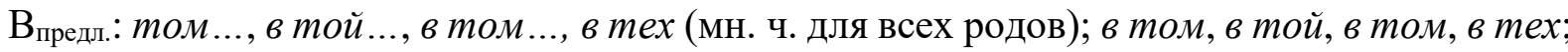
в том $_{1}$, в том 2 - 10 словоформ;

ДЛЯ: для того ..., для той..., для того ..., для тех...; для того, для той, для того, для тех; для того 1, для того $2-\mathbf{1 0}$

ДО: до того ..., до той..., до того ..., до тех ...; до того, до той, до того, до тех; до того, до $\mathrm{moго}_{2}-\mathbf{1 0}$

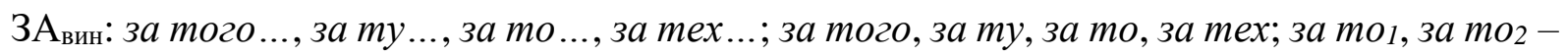
10;

3А за тем - 10; 
ИЗ: из того.., из той..., из того.., из тех...; из того, из той, из того, из тех; из того , из $\mathrm{mozо}_{2}-\mathbf{1 0}$

К: к тому.., к той..., к тому..., к тем...; к тому, к той, к тому, к тем; к тому, к тому 10

КРОМЕ: кроме того ..., кроме той..., кроме того ..., кроме тех...; кроме того, кроме той, кроме того, кроме тех; кроме того , кроме того - 10;

МЕЖДУ: между теми ...; между теми; а также между тем... и тем...(м., м.); между тем...( м.) и той...; между тем (ср.) и той; между той... и той...; между тем... и теми...; между той... и теми...; между тем и тем (м., ср.), между тем и тем (ср.); между той и той; между тем и теми, между той и теми; между теми и теми; между тем1 и тем; между тем и тем - 16;

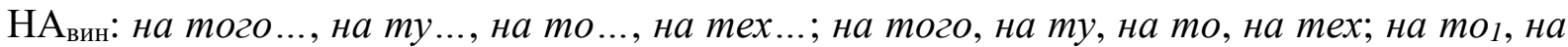
$\mathrm{mo}_{2}-\mathbf{1 0}$

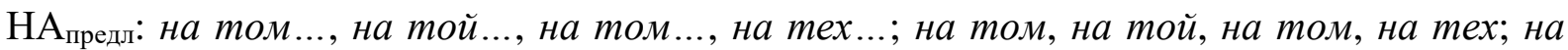
том $_{1}$, на том то $_{2} \mathbf{1 0}$

НАД: над тем..., над той..., над тем..., над теми ...; над тем, над той, над тем, над теми; над тем , над тем $-\mathbf{1 0}$

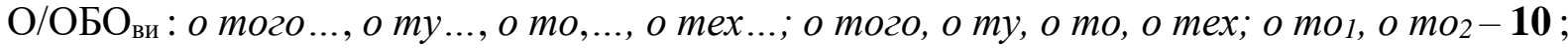

О /ОБ предл: о том..., о той..., о том..., о тех...; о том, о той, о том, о тех; о том , о $\operatorname{moм}_{2}-\mathbf{1 0}$

ОТ: от того..., от той..., от того..., от тех...; от того, от той, от того, от тех; от mого 1 , от того $_{2}-\mathbf{1 0}$;

ПЕРЕД: перед тем..., перед той.., перед тем .., перед теми ...; перед тем, перед той, перед тем, перед теми; перед тем , перед тем - 10;

ПО вин: по того..., по ту..., по то, по тех...; по того, по ту, по то, по тех; по то $\mathrm{mo}_{2}-\mathbf{1 0}$

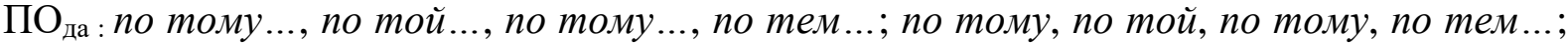
по тому, по тому $-\mathbf{1 0}$

ПОД вин : того..., под ту...., под то..., под тех ...; под того, под ту, под то, под тех; под $m o_{1}$, nод $\mathrm{mo}_{2}-\mathbf{1 0}$

ПОД предл: под тем ..., под той..., под тем ..., под теми ...; под тем, под той, под тем, под теми; под тем , под тем ${ }^{2}-\mathbf{1 0}$;

ПРИ: при том..., при той..., при том..., при тех; при том, при той, при том, при тех; при том 1 , при том 2 - 10;

РАДИ: ради того..., ради той..., ради того..., ради тех...; ради того, ради той, ради того, ради тех; ради того, ради того - 10;

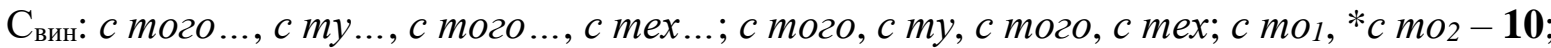

$\mathrm{C}_{\mathrm{тв}}:$ с тем..., с той..., с тем..., с теми...; с тем, с той, с тем, с теми; с тем1, с тем 10 словоформ.

У: у того ..., у той..., y того ..., y тех ...; y того, у той, y того, у тех; y того, y того 2 10 словоформ.

ЧЕРЕЗ: через того..., через ту.., через того..., через тех...; через того, через ту, через того, через тех; через то , через то $_{2}-10$ словоформ.

Всего 286 предложно-падежных словоформ $T$-слов.

Обратимся к $K$-слову - второму компоненту скрепы, который выступает в виде союза или союзного слова. Для нашего эксперимента возьмем союз что, который в традиции считается асемантичным и должен быть универсальным по сочетаемости. Соединим его с нашими $T$-словоформами, чтобы получить союзное средство. Из семи парадигм, представленных выше, с данным союзом сочетается только парадигма (7) - из 6 словоформ то2. В сочетании с первообразными предлогами мы можем получить следующие союзные скрепы, причем некоторые из них показались нам сомнительными (отмечены звездочкой): без того, что; в то, что; 
в том, что; для того, что; до того, что; за то, что; за тем, что; из того, что; к тому, что; кроме того, что; между тем, что и тем, что; на то, что; на том, что; над тем, что; о том, что; *o то, что; от того, что; перед тем, что; *по то, что; по тому, что; *под то, что; под тем, что; при том, что; ради того, что; *с то, что; с того, что; *у того, что; *через то, что - всего 28 скреп.

Верификация полученных скреп контекстами, имеющимися в нашем материале, а также извлеченными из Национального корпуса русского языка (НКРЯ), подтвердила наши подсчеты и сомнения, ибо некоторые из полученных скреп оказались единичными употреблениями в силу их архаичности, просторечности или семантического сдвига. Выявились также существенные различия в употребительности скреп - от нескольких документов до десятков тысяч. В качестве иллюстрации приведем по одному примеру на каждую скрепу с отдельными комментариями.

БЕЗ ТОГО, ЧТО: Наверное, Мишку нашли бы и без того, что я указал дом, но груз этой истории так или иначе лежит на мне (А. Сахаров). Всего 25 контекстов в НКРЯ (22 осн., 3 газ.)

В ТО, ЧТО: Называйте меня идеалисткой, но я твердо верю в то, ито принципы есть и у политиков (И. Плескачевская). Широко употребительная скрепа: 7-8 контекстов на страницу корпуса. Основным предикатом главной части является глагол верить и его дериваты.

В ТОМ, ЧТО: Опасность прошлого в том, что людей делали рабами, опасность будущего в том, что люди могут стать роботами (Эрих Фромм). Широко употребительная скрепа: 18119 документов / 52967 вхождений в основном модуле, 50093 / 60300 в газетном. Имеет очень продуктивную левую валентность для образования новых сцеплений - Дело / Суть / Вопрос / Проблема... в том, что. Сочетание Дело в том, что начиная с 1966 г. оказалось объектом внимания многих лингвистов - Е. Ф. Тарасенковой, Т. А. Колосовой, М. И. Черемисиной, Р. П. Рогожниковой, Г. А. Золотовой, М. В. Ляпон; обзор и литературу см. в (Лапынина 2013). Отдельные статьи о данной скрепе касаются места ее в кругу других синтаксических явлений (Шмелева 2006), степени ее грамматикализации по сравнению с аналогичными моделями (Добровольский, Пёппель 2018); расширения еe микрополя (Конюшкевич 2018). В состав скрепы вовлекаются далекие по значению слова дело, проблема, беда, вопрос, суть, идея, секрет, штука, фокус, закавыка, прелесть и др. В НКРЯ таких слов оказалось 51, и по выражаемым отношениям они в составе скреп синонимичны между собой. Скрепы указанного типа обладают способностью втягивать в свое поле союзы $a, н о$, однако, просто и др., образуя более сложные союзные соединения и формируя своеобразную парадигму деривационной модели.

ДЛЯ ТОГО, ЧТО: Селения, опричь сих, по сю сторону Вятки редки, редки и по сторонам, может быть, для того, что мало речек (А. Н. Радищев). Выражает причинные отношения; в основном корпусе почти все контексты относятся к XIX столетию: 1780 вхождений в 729 документах НКРЯ. В газетном модуле (140 документов, 143 вхождения) высказывания обнаруживают целевое значение с причинным оттенком и, с нашей точки зрения, не совсем корректны: Это делается для того, что помочь организму в покое лучше восстанавливаться после травмы (Комс. правда, 28.02.2013). Думаю, они сделали это не только для того, что насладиться музыкой, которая им нравится, но и чтобы выразить нам свою поддержку (Изв., 10.10.2012). Встречаемость таких построений: на каждой странице из 14-ти в среднем половина подобных конструкций. Примечательно, что в главной части о целевых отношениях содержатся сигналы - глаголы действия. Вторую половину вхождений представляют собственно целевые высказывания со скрепой для того, чтобы, но ее запись (для того, что бы) исказила статистику корпуса.

ДО ТОГО, ЧТО: Один из болгарских ученых договорился до того, что древние булгары, образовавшие потом болгарское государство, ведут свое происхождение из Тибета (В. В. Седов). Широко употребительная скрепа: 2629 документов, 4701 вхождение. В главной части таких структур выступают глаголы в основном с приставкой до- (доездились, доволновался, 
доустанавливались и др.). С глаголом доходить в главной части и с его формами образует сложную внутритекстовую скрепу-фразеосхему Дошло до того, что. Из всех 137 страниц газетного корпуса документов на заданную синтагму до того, что конструкции с глагольной формой дошло / доходило в моделях Дошло до того, что и Дело дошло до того, что составляют около 80\%, примерно по 7-8 примеров из 10 на странице; доля данных структур на одной странице в основном корпусе НКРЯ вдвое меньше. Парцелляция придаточной части вместе с элементами главной части свидетельствует о том, что синтаксический шов между частями в сложном предложении проходит не перед союзом, как показывает запятая, а перед предлогом, который входит в состав предикативной синтаксемы как часть ее форманта. Высказывания с фразеосхемой Вплоть до того, что являются парцеллами; в НКРЯ они составляют треть всех употреблений (52 на 156 документов в газетном модуле). Внутритекстовые отношения специфичны: высокая степень положения дел в порождающей ситуации представлена ретроспективно, в предшествующем фрагменте текста, а ее абсолютный негативный и отчасти абсурдный результат выражен в содержании придаточной части сложноподчиненного предложения. Аномалия привлекает и отталкивает, и это берет на заметку журналист, используя конструкции с до того, что и показывая типичность явления на абсурдном и единичном факте: В той семье очень тяжело. Вплоть до того, что детей забирать в приют хотят (Комс. правда, 15.11.2013).

3А ТО, ЧТО: Требовать от мужа восхищения за то, что ты его терпишь, - это, пожалуй, слишком (Ванда Блоньская). Очень частотная скрепа: 6319 документов, 16 945 вхождений в основном и $9084 / 10126$ в газетном соответственно. Доля омонимичных

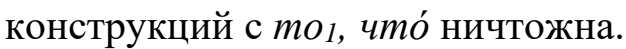

ЗА ТЕМ, ЧТО В другой раз я застал его за тем, что с деревенскими мальчишками он надувал через соломинку лягушку (М. Пришвин). 333 документа, 380 вхождений в основном модуле и 417 / 420 в газетном. Скрепа коррелирует с глаголами наблюдения в главной части.

ИЗ ТОГО, ЧТО: Депутаты исходят из того, что включение Минска в Евразийский экономический союз не исключает возможности более тесного сотрудничества между Беларусью и Европейским союзом (Н. Романова). В основном модуле - 2756 / 4312, в газетном - 2992 / 3161. Коррелирует с формами и дериватами глагола исходить; с деепричастной формой образована скрепа исходя из того, что: Теоретически можно было... даже убавить пламенную прыть. Исходя из того что Россия без нас, похоже, обойдется, а вот мы без нее, непонятно, обойдемся ли (М. Соколов).

К ТОМУ, ЧТО: Ирина постепенно привыкла к тому, что он уходит (В. Токарева). В основном 5149 / 8953, в газетном - 10360 / 10989, употребления с к тому

КРОМЕ ТОГО, ЧТО: В Исландии вообще знают о России хоть что-нибудь, кроме того, что там судят Pussy Riot? (Изв., 17. 08.2012). В основном - 1332 / 1841, в газетном -597 / 603. Наблюдается вариативность в употреблении запятой в скрепе.

МЕЖДУ ТЕМ, ЧТО И ТЕМ, ЧТО: Есть связь между тем, что студенты платят за обучение ... и тем, что бесчисленные работники университетской администрации покупают одну дорогую машину за другой (Изв., 06.12.2012). Малоупотребительная составная двухчастная скрепа в трехкомпонентной сложной конструкции. Из контекстов на 24 страницах в основном модуле $(248$ / 290) и на 12 в газетном $(115 / 118)$ только единичные употребления; превалируют скрепы с местоименными компонентами. Имеют место случаи (на наш взгляд, не совсем корректные) редукции второго состава скрепы: Возможно, никакой взаимосвязи между тем, что батареи вынесли наружу, и у вас стала промерзать стена, и нет (Комс. правда, 26.01.2010). При замене одной придаточной части на морфологизированную пропозицию второй состав скрепы элиминируется вместе с тог: Нет противоречия между тем, что их прибыль будет отдана в бюджет, и стратегическими приоритетами экономики (РБК Daily, 11.03.2010).

НА ТО, ЧТО: Лиџемер: человек, который убил обоих родителей и просит о снисхождении, ссылаясь на то, что он сирота (Авраам Линкольн). Очень частотная скрепа: 
9598 / 21155 - 28713 / 31560 (без снятия омонимии с то2, что́). Среди них контекстов с несмотря на то, что соответственно: 4770 / 8650 - 14243 / 15058.

НА ТОМ, ЧТО: Американские лидеры настаивают на том, что прочие народы и государства в существенно важных вопросах должны подчиняться благой воле великой заокеанской державы (Изв., 25.09.2002). Статистика: 2235 / 3251 - 3122 / 3218 (без снятия омонимии). Коррелирует с глаголами настаивать, сходиться и под.

НАД ТЕМ, ЧТО: Я работаю над тем, что я ломаю стереотипы (Комс. правда, 31.10.2013). В основном 583 / 709, в газетном - 306 / 311 (без снятия омонимии). Коррелирует с ментальными (задумываться, ломать голову, раздумыввать и др.) предикатами.

О ТОМ, ЧТО: Хочу писать стихи о том, что я хочу писать стихи (В. Соколов). Самая употребительная скрепа для выражения делиберативных отношений: 17417 / 53896 - 62425 / 79075.

*О ТО, ЧТО: Нуль плачет о то, что он нуль! (К. И. Чуковский. Роман 3. Н. Гиппиус // Речь, 1911; НКРЯ). В НКРЯ таких контекстов всего лишь 5 - один в основном модуле (пример выше) и 4 в газетном. Можно было бы предположить, что в газетном это опечатки сочетания о том, но контексты современны и принадлежат разным изданиям: Прежде всего речь идет о то, что идет снижение количества принятых законов (Комс. правда, 04.02.2011). «Весна постная» - так называет Православная церковь время Великого поста, напоминая о то, что пост - это время духовного расивета и пробуждения (РИА Новости, 10.03.2008).

ОТ ТОГО, ЧТО: От того, что грани между миром и войной стерты, планету лихорадит все больше (СБ, 23.01.16). В основном 2638 / 4 541, в газетном - $2941 / 3077$. Омонимия не снята, но контекстов с то1, что́ по 1-2 на страницу.

ПЕРЕД ТЕМ, ЧТО: Я себя называю человеком; я так рад и благоговею перед тем, что я русский (митрополит Антоний). Встречаемость: на каждой из 10 страниц основного модуля НКРЯ в среднем лишь по 2 контекста, в газетном - 13 контекстов из 30 . Как правило, управляющим предикатом в главной части является лексема страх.

*ПО ТО, ЧТО: - С отиом тебя мать в море не пускает, балует; любишь ты книжки читать, да рисовать; значит, нам родней приходишься! - Пошто? - По то, что мьл читать, да писать, да рисовать - мастера (Н. И. Гаген-Торн). Выявлено 5 контекстов в художественной речи, воспринимается как разговорное, просторечное, устаревшее, с семантикой причины.

ПО ТОМУ, ЧТО: О масштабе нового издательства можно судить по тому, что в нем выпускалось свыше 30 периодических изданий различного типа (Огонёк, 2014). Без снятия омонимии: 1036 / 1392 - 962 / 977. Основным управляющим предикатом в главной части выступает лексема судить и ее деепричастная форма судя, тяготеющая к статусу элемента составной скрепы судя по тому, что. Количество контекстов с данной скрепой из числа выше составляет почти половину - 423 / $500-730$ / 735.

*ПОД ТО, ЧТО: Нас сегодня подводят под то, что мы преступники, и во время этой передачи вы тоже обращались ко мне как к спекулянту (А. Тарасов). Единственный контекст в НКРЯ.

ПОД ТЕМ, ЧТО: Как возможно априори подписываться под тем, ито адвокат может прекратить уголовное дело? (Адвокат, 01.12.2004). 8 контекстов из 20 в основном корпусе и 12 из 27 в газетном. Управляющий предикат в главной части - глагол nодписаться / nodnucblваться и его формы.

ПРИ ТОМ, ЧТО: Каждый ввозимый на территорию страны зарубежный фильм (при том, что квот на ввоз нет) облагается таможенным налогом (Изв., 04.02.2003). Широко употребительное союзное средство: 1182 / 1536 - 3991 / 4 145. В сочетании с союзом и и местоимением это образует межфразовую или вставную составную скрепу со значением обратной обусловленности: У него даже нет собственного автомобиля - ездит на служебной «десятке». И это при том, что некоторые из заказываемых ему машин стоят более сотни 
долларов (Автопилот, 15.06.2002). Количество контекстов из числа выше - 300 / 332 - 1168 / 1186.

РАДИ ТОГО, ЧТО: - Не связать же себя навеки ради того, что глупьй случай вдруг сделал меня отцом! (К. М. Станюкович). Из 106 вхождений в основном корпусе 8 контекстов из 10 на каждой странице употреблены с данным союзным средством, причем преимущественно в художественной литературе XIX-XX вв. и с семантикой скорее причины, нежели цели; в газетном модуле подобные контексты отсутствуют, хотя единичные вхождения из периодических изданий имеют место в основном корпусе: Неужели Иисус мучился ради того, что Обыватель и Alехеу могли, все забыв и свесив челюсть от восторга, наслаждаться своими плазменными телевизорами и другими дорогими игрушками? (интернет-альманах «Лебедь», 16.11.2003).

*C ТО, ЧТО: Контексты в НКРЯ отсутствуют; на наш взгляд, они с данным союзным средством невозможны.

С ТОГО, ЧТО: Нужно начать с того, что Домрачева - это яркий талант (Изв., 23.04.2014). Количество без снятия омонимии: $1885 / 2625$ - 2222 / 2 264. В большинстве контекстов управляющим предикатом главной части выступает глагол начать(ся) и его формы.

*У ТОГО, ЧТО: У того, что «Росгосстрах» растет быстрее рынка, две причины (РБК Daily, 28.04.2004). Малоупотребительна скрепа: 2 контекста в основном модуле и 5 в газетном. Все контексты построены по модели: У того, что имеет место $P$, есть причиныл.

*ЧЕРЕЗ ТО, ЧТО Может, через то, что богато живешь, и дочь к нам ушла? (М. Шолохов). Стилистически маркированная скрепа со значением причины, контексты имитируют устаревшую речь или просторечие в художественной литературе XX века (встречается в речи персонажей М. Шолохова); в основном корпусе - 35 контекстов, в газетном отсутствуют.

Вывод. Проведенный эксперимент показал, что границы скрепы как целостной языковой единицы обусловлены прежде всего фактором коммуникативных задач и текста как конечного продукта коммуникативной деятельности носителей языка. И только частотность употребления и исчислимость вариантов определяют место такой скрепы в системе языка. Причем фактор исчислимости обеспечивает категориальность скрепы как представителя того или иного класса соединителей, а фактор употребительности определяет место (ядро или периферийные зоны) скрепы в структуре функционально-грамматического поля союза.

В перспективе предстоит экспериментально получить скрепы с двумя прономинальными компонентами. Ожидается, что а) скреп окажется гораздо больше, б) их количество исчислимо, в) употребительность избирательна.

\section{Литература}

Апресян, Ю. Д., Пекелис, О. Е. «Союз». [В:] Русская корпусная грамматика, 2012. Web: rusgram.ru. 21.01.2021.

[Apresian, JU. D., Pekelis, O. E. «Sojuz». [V:] Russkaja korpusnaja grammatika, 2012. Web: rusgram.ru. 21.01.2021.]

Всеволодова, Майя В. Теория функционально-коммуникативного синтаксиса: фрагмент прикладной (педагогической) модели языка. М.: МГУ, 2000.

[Vsevolodova, Majja V. Teorija funkcional'no-kommunikativnogo sintaksisa: fragment prikladnoj (pedagogicheskoj) modeli jazyka. M.: MGU, 2000.]

Всеволодова, М. В., Кукушкина, О. В., Поликарпов, А. А. Русские предлоги и средства предложного типа. Материалы к функционально-грамматическому описанию реального употребления. Кн. 1: Введение в объективную грамматику и лексикографию русских предложных единиц. М.: ЛИБРОКОМ, 2014.

[Vsewolodowa, M. W., Kukushkina, O. W., Polikarpov, A. A. Russkije predlogy i sredstwa predlozhnogo tipa. Materialy k funkcional'no-grammatycheskomu opisaniju real'nogo upotreblenija. 
Kn. 1. Vvedenie w objektyvnuju grammatiku I lexikografiju russkih predlozhnykh jedynic. M.: LIBROKOM, 2014.]

Добровольский, Д., Пёппель, Л. «О грамматикализации конструкций». [В:] Тезе и резимеи XVI међународн. Конгр. Слависта. Београд, 2018. У 2 т. Т. 1. С. 273.

[Dobrowol'skij, D., Pöppel', L. "O grammatikalizacii konstrukcij». [V:] Teze i rezimei XVI meђunarodn. Kongres Slavista. Beograd, 2018. U 2 t. T. 1. S. 273.]

Завьялов, Виктор Н. Морфологические и синтаксические аспекты описания структуры русских союзов. Хабаровск: ДВГГУ, 2008.

[Zav'jalov, Wiktor N. Morfologicheskije i sintaxicheskije aspekty opisanija structury russkih sojuzov. Khabarovsk: DWGGU<2008.]

Загнітко, Анатолий. «Функційно-лексикографічна граматика службовості». Лінгвістичні студії 24. Донецьк: ДонНУ, 2012, 8-15.

[Zagnitko, Anatolij. «Funkcijno-leksikografichna gramatika sluzhbovosti»[V:] Lingvistychni studiyi 24. Donec'k: DoNNU, 2012, 8-15.]

Конюшкевич, Мария И. «Семантический диапазон и синтаксические функции слова то в сложноподчиненном предложении». [В:] Лингвистические идеи В. А. Белошапковой и их воплощение в современной русистике. Тюмень: Мандар и $\mathrm{K}^{\mathrm{a}}, 2010,61-68$.

[Koniushkevich, Marija I. «Semanticheskij 103d r103son I syntaxicheskije funkcii slova to v slozhnopodchinionnom predlozhenii» [V:] Lingvistycheskije idei V. A. Beloshapkovoj 103d r voploschenije v sovremennoj rusistike. Tjumen': Mandar i $\mathrm{K}^{\mathrm{a}}$, 2010, 61-68.]

Конюшкевич, Мария И. «Влияние языка СМИ на образование фразеосхем типа Дело в том, что» [В:] Медиалингвистика 1. Т. 5. 2018, 84-96.]

[Koniushkevich, Marija I. «Vlijanije jazyka SMI na obrazowanije frazeoshem typa Delo v tom, chto» [V:] Medialingvistika 1. T. 5. 2018, 84-96.]

Лапынина, Н. Н. «О текстообразующей функции стандартизованной единицы Дело в том, что» [В:] Вестник ВГУ. Серия Лингвистика и межкультурная коммуникация2. 2013, 120 124.

[Lapynina, N. N. «O textoobrazujuschej funkcii standartizovannoj jedynicy Delo v tom, chto» [V:] Vestnik VGU. Seria Lingvistika i mejkulturnaja kommunikacija 2. 2013, 120-124.]

Лингвистический энциклопедический словарь. М.: Сов. Энциклопедия, 1990.

[Lingvisticheskiyj enciklopedycheskij slovar'. M.: Sov. Enciklopedija, 1990.]

Ляпон, Майя В. Смысловая структура предложения и текст. К типологии внутритекстовых отношений. М.: Наука, 1986.

[Lapon, Majia V. Smyslovaja struktura predlozhenija i text. K typologii vnutrytextovyh otnoshenij. M.: Nauka, 1986.]

Объяснительный словарь русского языка: Структурные слова: предлоги, союзы, частицы, междометия, вводные слова, местоимения, числительные, связочные глаголы. М., 2003. 421 с.

[Objasnitel'nyj slovar' russkogo jazyka: Strukturnye slova: predlogi, sojuzy, chasticy, mezhdometija, vvodnye slova, mestoimenija, chislitel'nyje, swiazochnye glagoly. M., 2003. 421 s.]

Прияткина, Алла Ф. «Союз и его функциональные аналоги» [B:] Синтаксические связи в русском языке. Владивосток, 1978.

[Prijatkina, Alla F. «Sojuz i jego funkcionalnye analogy» [V:] Syntaxsicheskie sviazi v russkom jazykie. Vladivostok, 1978.]

Русская грамматика. М.: Наука, 1980.

[Russkaja grammatika. M.: Nauka, 1980.]

Русский язык. Энциклопедия. М.: Большая Российская энциклопедия, 1997.

[Russkij jazyk. Enciklopedija. M.: Bol'shaja Rossijskaja Enciklopedija. 1997.]

Словарь служебных слов русского языка. Авт. колл.: А. Ф. Прияткина, Е. А. Стародумова и др. Владивосток, 2001.

[Slovar' sluzhebnyh slov russkogo jazyka. Avt. koll.: A. F. Prijatkina, E. A. Starodumova 103d r. Vladivostok, 2001.] 
Словарь структурных слов русского языка. М.: Лазурь, 1997.

[Slovar' strukturnyh slov russkogo jazyka. M.: Lazur', 1997.]

Служебные слова в лексикографическом аспекте [Электронный ресурс]: кол. монография. Владивосток : Дальневост. федерал. ун-т, 2017. Web 2017.pdf Диск (yandex.by).

[Slujebnyje slova v lexikograficheskom aspekte [Electronnyj resurs]: koll. Monografija. Vladivostok: Dal'nevost. federal. un-t, 2017. Web 2017.pdf Disk (yandex.by).]

Черемисина, Майя И., Колосова, Татьяна А. Очерки по теории сложного предложения. Новосибирск: Наука, 1987.

[Cheremisina, Majia I., Kolosova, Tatjana A. Ocherki po teoriji slozhnogo predlozhenija. Novosibirsk: Nauka, 1987.]

Черемисина, Майя И. «Об изъяснительной конструкции с факультативным управляемым местоимением то» [В:] Функииональный анализ синтаксических структур. Иркутск, 1982.

[Cheremisina, Majia I. «Ob iz'jasnitel'noj konstrukcii s fakultativnym upravlajemym mestoimenijem to» [V:] Funkcional'nyj analiz syntaxicheskih struktur. Irkutsk, 1982.]

Шмелева Т. В. «Дело в том, что...» [В:] Асимметрия как приниип функиионирования языковых единиц. Новосибирск, 2006, 145-153.

[Shmeleva, Tatjana V. «Delo v tom, chto...» [V:] Asimmetrija kak princip funkcionirowanija jazykovyh jedinic. Novosibirsk, 2006,145-153.]

\section{THE CALCULABILITY OF SYNTAXIC RELATIONS INDICATORS AS A FACTOR OF THEIR CATEGORIALITY IN THE LANGUAGE SYSTEM Maria Konyushkevich \\ Independent researcher, Grodno, Belarus}

Abstract

Background: On the basis of the definitional analysis, the insufficiency of identified complex of seven differentiating features for establishing the boundaries of the conjunction categorial field and the number of its constituents is proved. Additional criteria to confirm the conjunction nature of peripheral "keep-clips" are needed.

Purpose: As one of them, the factor of calculability is proposed, which is found when the left and right valency of the "keep-clip" is taken into account as a predicate.

Results: As the argument the "keep-clip" to, chto is reviewed, the wordforms of each element of which, by their composition, form separate independent "keep-clips", and the number of them is countable. The hypothesis is proved experimentally: the full paradigm of $T$-wordforms is 60 units; in conjunction with 21 simple prepositions (taking into account case - 28), multiplying 60 by 28 , you can get 1680 prepositional-case forms tot (to). 256 prepositional-case wordforms are formed practically, and taking into account the paradigm $t_{2}$ of 6 wordforms and their compatibility with the conjunction chto, only 28 "keep-clip" are obtained. Verification of the obtained "keep-clips" by contexts from the National Corpus of the Russian language confirmed the hypothesis and revealed the uniqueness of each "keep-clip" as a separate integral unit. The article contains examples of all the "keep-clips" uses with the necessary comments.

Discussion: The categoriality of conjunction means is determined by the factor of their calculability, and the conjunction function is determined by the use in communication. In the future, it is necessary to obtain experimentally "keep-clips" with two pronominal components (to, chto). It is expected that a) there will be much more "keep-clips", b) their number is quantifiable, b) their use is selective.

Keywords: conjunction, differentiating feature, "keep-clip", wordform, valency, paradigm. 
Vitae

Maria Konyushkevich, Doctor of Philology, Professor. Independent researcher. Research interests: bilingualism, functional grammar, relational grammar, media linguistics, grammar of text, lexicography.

Надійшла до редакції 25 березня 2021

Рекомендована до друку 8 квітня 2021 року

Микола Степаненко

ORCID: orcid.org/0000-0002-6727-1265

DOI 10.31558/1815-3070.2021.41.10

УДК $811.161 .2 ’ 367$

\section{ЛОКАТИВНИЙ ОРІЕНТИР ЯК МАРКЕР КОНЦЕПТУАЛІЗАЦЇ̈ ПРОСТОРУ}

У статті схарактеризовано механізм концептуалізації локативності за участю різних мовних засобів. Розкрито, зокрема, роль просторового орієнтира, репрезентованого припредикатним поширювачем речень структурної моделі Sub + Praed + Adv loc із семантичним описом «носій прочуесуальної ознаки + прочуесуальна ознака + просторові межі реалізації процесуальної ознаки», у встановленні конкретного типу статичної, директивної або транзитивної локативності. Вирізнено такі форми ідентифікування локативного орієнтира, як симетрійність / асиметрійність, реальність / ірреальність (метонімійність), з'ясовано специифіку вербалізації ї.

Ключові слова: механізм локалізачї, просторовий (локативний) орієнтир, статичність / директивність / транзитивність, симетрійна / асиметрійна концептуалізація простору, реальна / ірреальна (метонімійна) концептуалізація простору.

Постановка наукової проблеми. Відомо, що простір є важливим атрибутом матерії, загальною формою буття іiі, тобто «немає матерії, яка б не була наділена просторовими властивостями, як і не існує і простору самого по собі, поза матерією й незалежно від неї» (Кобозева, 153). Онтологічна категорія простору одержала різнобічну інтерпретацію на рівні окремих наук, а також тих, що з'явилися на їх покордонні. Філософське трактування локативності фокусує в загальних контурах усі їі іманентні характеристики. Воно слугує засадничою базою для лінгвістичного інтерпретування категорії локативності. У мовознавстві під локативністю розуміють «семантичну категорію, до якої входять усі різновиди просторового значення» («Українська мова», 337). Вона «виражає відображені у свідомості людей різноманітні просторові відношення предметів і явищ, зокрема їхнє місцеперебування, напрямок руху, контактність та дистантність розташування і под.» (там само). Конкретним репрезентантом просторових відношень $\epsilon$ те або те обмежене певними координатами місце. Місце - це простір, що являє собою верхній шар маси речовини, рідини й т. ін., на якій щось відбувається, хтось або щось розміщується, реальний або уявлюваний простір, на якому хтось перебуває або щось розташовується. Складний механізм локативності найоб'єктивніше віддзеркалює речення $з$ такими денотативними ситуаціями: «хтось (щось) десь перебуває», напр.: Народ молився по костьолах (А. Чайковський); «хтось (щось) кудись прямує з фіксацією просторових координат - старту, фінішу, старту й фінішу водночас», напр.: Вилетіли з краю далекого журавлі (Д. Загул), Він пойхав на Далекий Схід (Ю. Яновський), Люди з першого залу вискакують на коридор (О. Гаврилюк); «хтось (щось) кудись прямує без фіксаиії просторових координат», напр.: Біжать через місток семінаристи (Т. Осьмачка). 